\title{
Lifestyle precision medicine: the next generation in type 2 diabetes prevention?
}

Pascal M. Mutie', Giuseppe N. Giordano ${ }^{1}$ and Paul W. Franks ${ }^{1,2,3,4^{*}}$

\begin{abstract}
The driving force behind the current global type 2 diabetes epidemic is insulin resistance in overweight and obese individuals. Dietary factors, physical inactivity, and sedentary behaviors are the major modifiable risk factors for obesity. Nevertheless, many overweight/obese people do not develop diabetes and lifestyle interventions focused on weight loss and diabetes prevention are often ineffective. Traditionally, chronically elevated blood glucose concentrations have been the hallmark of diabetes; however, many individuals will either remain 'prediabetic' or regress to normoglycemia. Thus, there is a growing need for innovative strategies to tackle diabetes at scale. The emergence of biomarker technologies has allowed more targeted therapeutic strategies for diabetes prevention (precision medicine), though largely confined to pharmacotherapy. Unlike most drugs, lifestyle interventions often have systemic health-enhancing effects. Thus, the pursuance of lifestyle precision medicine in diabetes seems rational. Herein, we review the literature on lifestyle interventions and diabetes prevention, describing the biological systems that can be characterized at scale in human populations, linking them to lifestyle in diabetes, and consider some of the challenges impeding the clinical translation of lifestyle precision medicine.
\end{abstract}

Keywords: Review, Type 2 diabetes, Lifestyle factors, Overweight/obesity, Precision medicine, Biomarkers, Intervention, Prevention

\section{Background}

Prediabetes, a state of chronically elevated but nondiabetic blood glucose, is one of the greatest healthcare challenges of our time, affecting more than 100 million people in Europe alone [1]. The term 'prediabetes' implies a state of glucose dysregulation destined to worsen, with various health agencies stressing that those affected are at high-risk of developing type 2 diabetes (T2D). However, annually, only $5-10 \%$ of people with prediabetes will develop the disease, with $10 \%$ regressing to normoglycemia [2]. Moreover, in those who remain prediabetic, there is scant evidence that elevated, nondiabetic blood glucose concentrations are causally related with clinical endpoints, and therefore intensively intervening solely on the basis of glycemia may not be cost-effective [3]. Nevertheless, if the subgroup(s) of people with prediabetes who progress to diabetes could

\footnotetext{
* Correspondence: paul.franks@med.lu.se

'Department of Clinical Sciences, Genetic and Molecular Epidemiology Unit, Lund University, Skåne University Hospital, SE-205 02 Malmö, Sweden ${ }^{2}$ Department of Public Health \& Clinical Medicine, Umeå University, Umeå, Sweden

Full list of author information is available at the end of the article
}

be distinguished with reasonable certainty, the case for early intervention would be compelling given the largely intractable nature of the disease, primarily due to the manner in which the insulin secreting beta-cells deteriorate, the absence of accessible beta-cell restorative therapy, and the devastating consequences of diabetic complications.

T2D is primarily a disease of dysregulated carbohydrate metabolism, influenced by lipid storage and metabolism [4]. The disease occurs when the beta-cell insulin secretory capacity falls below the body's requirements for insulin production, which are governed chiefly by the quantity of glucose entering the blood from the gut (dietary sources) or the liver (gluconeogenesis), and the rate at which glucose is consumed and metabolized in tissues and organs; this process is in turn governed by peripheral insulin sensitivity (influenced by intra-cellular lipid accumulation) and non-insulin-dependent glucose trafficking (attributable to exercise). Thus, it is unsurprising that the foundations of a westernized lifestyle (poor diet, physical inactivity, and obesity) are the core modifiable 'exposures' believed to cause T2D and the targets of most non-pharmacologic diabetes prevention programs [5]. 
However, even the most successful lifestyle interventions tend to delay (by roughly 3 years) rather than prevent the disease from occurring [6]. Moreover, there appears to be extensive between-individual variability in susceptibility to lifestyle risk factors [7] and response to therapies [8]. Thus, there is an unmet need for more effective lifestyle therapies.

The apparent inter-individual variability in susceptibility and response to lifestyle factors in diabetes has motivated the view that tailoring lifestyle interventions to a person's biological characteristics could help optimize diabetes prevention and treatment. This appealing concept has motivated a burgeoning direct-to-consumer industry that promises to match diet and exercise products and services to the customer's personal genomic (and other omic) characteristics. Indeed, the largest public-sector medical research agencies (NIH and European Union) are also investing heavily in research focused on this topic. Nevertheless, there is considerable skepticism about lifestyle precision medicine, particularly when commercialized [9]; even where biomarkers have been conclusively linked to susceptibility and response phenotypes, many barriers to clinical translation persist.

Many healthcare agencies advocate a lifestyle characterized by daily physical activity, a healthy diet, moderate alcohol consumption, maintenance of normal body weight, sound psychological health, and non-smoking $[10,11]$. These recommendations are based on data from large epidemiological studies and randomized controlled trials (RCTs) indicating that these lifestyle factors lower risk of, or help prevent, T2D at a population level [11]. The most impactful risk factor and intervention target is excess body weight, as being obese (BMI $\left.30-35 \mathrm{~kg} / \mathrm{m}^{2}\right)$ or very obese $\left(\mathrm{BMI} \geq 35 \mathrm{~kg} / \mathrm{m}^{2}\right.$ ) conveys a 20- to 40 -fold increased relative risk of T2D compared with being lean $\left(\mathrm{BMI}<23 \mathrm{~kg} / \mathrm{m}^{2}\right)$ [12].

Herein, we review the concept of lifestyle precision medicine in T2D. Specifically, we summarize the published evidence on lifestyle risk factors and preventive interventions in T2D, briefly discussing the limitations of existing approaches focusing on lifestyle interventions for T2D prevention, and explore how harnessing biomarker technologies might help optimize these strategies. Furthermore, we describe evidence of differential response to lifestyle interventions based on unique genetic traits, as well as functional evidence of the biomolecular basis of these responses. Finally, we describe current omics technologies that can be applied to identify and stratify populations based on an individual's unique genotype.

\section{Methods}

\section{Literature search strategy}

We reviewed the literature for evidence of modifiable lifestyle exposures that either raise or lower the risk of
T2D. A detailed overview of each of the papers reviewed is given in Additional file 1: Table S1. The findings are summarized later in this review.

We searched the PubMed online database for papers using the search terms "(Cohort Studies[MeSH] OR Nested case cohort study[MeSH] OR Randomized Control Trial[MeSH]) AND (Lifestyle[MeSH] OR Environmental Exposures[MeSH]) AND (Blood glucose [MeSH] OR HbAlc [MeSH] OR Impaired fasting glucose OR Impaired glucose tolerance OR Dysglycemia OR Type 2 diabetes[MeSH] OR Glucose Intolerance[$\mathrm{MeSH}]$ ) NOT review". The search was restricted to human studies only and age 45 years and above without restriction on the year of publication.

The search retrieved information for 676 papers. After title scanning, 197 articles were selected as potentially relevant and their abstracts were reviewed, with 65 of these papers being relevant for full review. Additionally, further papers were identified through ancestral searches of bibliographies; therefore, a total of 75 papers $[6,12-85]$ were used to compile the evidence summary reported below.

\section{Review}

Published evidence of lifestyle in T2D risk and prevention The review highlighted several well-conducted RCTs demonstrating the effect of lifestyle interventions in reducing the risk of T2D. In the Diabetes Prevention Program (DPP; $\mathrm{n}=3234$ ), an intensive lifestyle intervention was superior to a pharmacological intervention of metformin in reducing the incidence of diabetes over 2.8 years of follow-up compared to placebo [79]. The incidence of T2D was reduced by $58 \%$ (95\% CI $48-66 \%)$ in the lifestyle group and by $31 \%$ (95\% CI $17-43 \%$ ) in the metformin group compared to the placebo group. Follow-up of the same cohort for a further 10 years showed persistent beneficial effects from lifestyle interventions, with $\mathrm{T} 2 \mathrm{D}$ onset being delayed by approximately 4 and 2 years in the lifestyle and metformin groups, respectively, compared to placebo [6]. The Finnish Diabetes Prevention Study (DPS; $\mathrm{n}=522$ ) implemented a similar lifestyle protocol, which also conveyed a 58\% (95\% CI 30-70\%) reduction in diabetes incidence [86]. Both protocols focused on overweight or obese $\left(\right.$ BMI $\left.>25 \mathrm{~kg} / \mathrm{m}^{2}\right)$ participants with impaired glucose regulation, and promoted a $5-7 \%$ weight reduction, a total and saturated fat intake reduction, an increase in fiber intake, and regular exercise. Numerous other trials focusing on lifestyle interventions in a range of ethnic groups and study settings followed [20, 29, 58, 73], reporting reductions in diabetes incidence of comparable or lesser magnitude to the DPP and Finnish DPS trials. Long-term follow-up indicates that benefits of intensive lifestyle modification on diabetes incidence are sustained for up to 20 years [68]. 
Large prospective cohort studies have also reported robust associations between lifestyle exposures and T2D in diverse populations. For example, in the Kailuan prospective study $(\mathrm{n}=50,656)$ [15], changes from the ideal cardiovascular health status score were inversely associated with risk of T2D over an average 3.8 years of follow-up. In the Finnish Twins Study $(n=20,487)$ [55], leisure-time physical activity reduced the risk of incident T2D in both monozygotic and dizygotic twins who were physically active compared to their sedentary siblings (HR 0.6, 95\% CI 0.43-0.84, $P=0.003$ ), even after factoring in familial risk and home environment. In the Strong Heart Study [64], among American Indians $(n=1651)$ followed for 10 years, high physical activity was associated with a reduced risk of T2D (OR 0.71, 95\% CI 0.510.99 in the highest quartile compared to those who reported no physical activity), although the estimates were attenuated and became non-significant after adjusting for adiposity. A similar beneficial impact of physical activity in T2D incidence was observed in a European case-cohort study of nearly 30,000 adults [46], and in 68,000 female US health professionals [78].

Yates et al. [5] systematically reviewed the literature on RCTs testing the efficacy of diet and/or exercise interventions in the prevention of T2D. Of the eight trials reviewed, most involved a combined diet and exercise intervention. Compared with standard of care, the reduction in the risk of developing T2D attributed to the lifestyle interventions averaged 50\% during the trial's randomization phase. Long-term follow-up of the DPP Outcomes Study [6], the Finnish DPS [87], and the China Da Qing Diabetes Prevention Study [68], all indicated that the reduced risk of diabetes attributable to lifestyle intervention is sustainable for 10-20 years postrandomization. Although attempts have been made to parse out the relative contributions of diet and exercise in diabetes prevention, most lifestyle trials have not been designed for this purpose, and generally assess diet and exercise using self-report methods prone to respondent bias. However, Slentz et al. [88] recently reported that, within an exercise-only intervention trial, high volume moderate-intensity exercise $(\sim 18.2 \mathrm{~km} /$ week of walking) alone substantially reduced glucose tolerance in people at high risk of T2D, despite modest effects on body weight reduction $(\sim 2 \mathrm{~kg})$. Diet-only interventions, such as that used in the PREDIMED trial focusing on Mediterranean-style diets [89], have yielded reductions in diabetes risk of approximately 50\% compared with a control intervention.

RCTs are often considered the gold-standard in the hierarchy of causal evidence, as double-blind, placebo controlled trials are generally robust to confounding and reverse causality. However, in lifestyle intervention trials, masking treatment allocation from the participant and investigators is extremely challenging, which may result in compensatory behaviors that introduce bias and confounding - a rarely discussed caveat that affects the validity of data from lifestyle RCTs. Nevertheless, abundant epidemiological studies and clinical trials have implicated multiple lifestyle factors in the development of T2D.

Poorer social environments, within which fewer resources and opportunities exist to maintain healthy lifestyles, convey an increased risk for many diseases, including obesity and T2D [90]. Studies in twins suggest that the relationship between socioeconomic status and obesity may be modified by genetic variation [91]. Using data from the UK Biobank, Tyrrell et al. [92] studied the interaction of 66 established BMI-associated variants and 12 obesogenic lifestyle exposures in obesity; the authors extended previous discoveries of genetic interactions with physical activity [93, 94] and TV viewing [95], and identified a novel interaction with the Townsend Deprivation Index [96].

Evidence on the association between environmental exposures (e.g., to particulate matter and persistent organic pollutants) and T2D has yielded mixed results: some studies showed a statistically significant relationship between long-term exposure and risk of T2D [18], with higher risk attributed to traffic-specific pollution [33, 47], whereas others found no association [21]. Furthermore, one study reported an association of traffic-specific pollution exposure with T2D risk in women [51]. Exposure to arsenic [24, 81] and persistent organic pollutants was also significantly associated with T2D [19, 61], but no such association was seen for cadmium exposure $[35,44]$.

Coffee consumption has been associated with lower risk of dysglycemia in observational studies [48], yet recent Mendelian randomization analyses do not support a causal relationship [97, 98]. In the Adventist Health Studies [65] and the Women's Health Study [75], consumption of red and processed meats was significantly associated with increased T2D risk. Intake of dairy products was not consistently related to T2D, cardiovascular disease, or all-cause mortality [38]. In the EPIC InterAct Study [99], dietary fiber consumption was associated with lower T2D incidence, though this was partially explained by body weight. While psychosocial health is an important risk factor, especially in the elderly [13], the relationship between depressive symptoms and dysglycemia may be mediated by other factors such as lifestyle [14]. Working overtime was significantly associated with risk of T2D among nurses [70] and among Japanese men working more than 50-hours overtime per month [83].

Although the literature on specific lifestyle exposures and T2D risk is extensive, all studies used to inform guidelines are based on the average estimated effects in the studied population, which would be acceptable if susceptibility to risk factors and response to preventive 
interventions were homogeneous. However, there is tremendous between-person variability in susceptibility and response to lifestyle exposures, which undermines the value of uniform recommendations. Indeed, it is estimated that the majority of people undergoing exercise interventions do not show an adequate response [8]. There are various reasons why there may be a lack of response to lifestyle interventions, many of which are irrelevant to individual biology; these factors are listed in Table 1. Ignoring these factors when estimating the likely impact of lifestyle precision medicine in T2D would substantially overestimate its value [100]. Nevertheless, harnessing genotypes and other omic variants to optimize lifestyle interventions for population subgroups may significantly impact individual and population-scale diabetes trajectories. Such approaches are especially appealing in prediabetes, where measures of glycemia alone are inadequate, and additional biomarkers are likely needed to predict or prevent progression to fullblown disease.

Most contemporary studies of the interplay between genetic and lifestyle factors have focused on gene variants and lifestyle exposures previously associated with the disease of interest. Few of the exposures mentioned above have been studied in the context of gene-lifestyle interactions. A systematic search of the PubMed database (conducted on July 19, 2017; see Additional file 1: S1 for the search string) identified 30 original research articles and 13 review articles or commentaries. Of these, only seven publications focused on T2D as the outcome; additional ten relevant papers were identified through ancestral searches some of which are RCTs [101-106]. Others reported on prospective observational studies examining gene variant interactions with different diet components [107-110] and with physical activity $[107,111]$.

\section{Types of biomarkers \\ Genotypes}

Two contrasting approaches have been used most in studies of genetics and lifestyle in complex disease traits. The dominant strategy has been the use of genome-wide association studies (GWAS), which leverage massively parallel genotyping technologies to interrogate variation across the genome, in a way that is agnostic to prior knowledge about genes, lifestyle, or disease. The second strategy involves studies focused on animal or human biology, through which genes and pathways have emerged as subsequent targets of epidemiological studies and/or clinical trials. The published findings from the latter are generally far less reproducible than those from studies using GWAS-based approaches.

\section{Examples of GWAS-based studies connecting lifestyle and T2D}

The use of large cohort collections within which genetic variation, self-reported measures of macronutrient intake, and other relevant factors are included have facilitated the discovery of variants associated with protein and carbohydrate intake. The CHARGE consortium reported

Table 1 Factors influencing response to lifestyle interventions

\begin{tabular}{ll}
\hline Factor & Definition \\
\hline Behavioral compensation & In most cases, assignment to lifestyle interventions in clinical trials cannot be masked from the \\
& participants or investigators. This may prompt changes in behavior that are not the main objective \\
of the trial and which differ by treatment arm, or may cause investigators to treat participants in the & lifestyle and control arms differently. These sources of bias may underlie what appears to be variability \\
in treatment response.
\end{tabular}

Regression to the mean

Adherence

Background heterogeneity in behaviors
Trials that include only one outcome assessment, and which assess change in the outcome as the difference between the baseline and follow-up measure, are likely to be prone to regression dilution bias (or regression to the mean). This phenomenon occurs because most assessments are made with some degree of error, meaning that, in some participants, the change in the outcome will be underestimated and in others it will be overestimated. Where the outcome is assessed using a physical stress test (such as on a treadmill or bicycle ergometer), differences in effort at the beginning and end of the trial will also contribute to the apparent variability in treatment response. This problem could in principle be overcome in a randomized controlled trial by conditioning treatment response on response to the control intervention, although this is not conventionally done in studies of responders and non-responders, which generally focus only on intervention groups.

Variability in the extent to which participants follow protocols in clinical trials (adherence) is likely to play a significant role in determining the extent to which an intervention appears to work. Although adherence is usually monitored in trials, monitoring adherence to lifestyle interventions is challenging, as the accurate and precise assessment of diet and exercise is notoriously difficult. The use of self-reported diet and/or exercise instruments to monitor adherence is likely to be insufficient in lifestyle trials, as participants in the active intervention arm may feel pressured to provide confirmatory responses to lifestyle questions.

Lifestyle interventions are often comprised of around 150 mins/week contact time, accounting for approximately $2 \%$ of all waking time. During the $98 \%$ non-contact time, participants' behaviors are likely to vary considerably, influencing the extent to which the trial's outcomes change. 
robust associations between $F T O$ variants and dietary protein intake in 177,000 adults [112], whereby each copy of the rs9939609 'A' allele was associated with a mean of $0.08 \%$ (95\% CI $0.06-0.10 \%, P=2.4 \times 10^{-16}$ ) higher protein intake; weak associations between the 'A' allele and lower total energy intake and lower dietary carbohydrate intake were also reported. The latter contradicts data from studies in children using objective measures of total energy intake, where the ' $\mathrm{A}$ ' allele was associated with higher total energy intake [113].

There is compelling evidence that the hepatokine fibroblast growth factor 21, and variation at the gene that encodes it (FGF21), helps regulate energy homeostasis [114] and influences macronutrient and alcohol preference in animals and humans [115-118]. The FGF21 hormone is induced by metabolic stress, including ketogenesis and dietary carbohydrate consumption. FGF21 was initially suggested as a therapeutic agent for diabetes [114] by the pharmaceutical giant Eli Lilly and Co. Exogenous FGF21 infusion lowers blood glucose and triglyceride concentrations and improves pancreatic beta-cell function in $\mathrm{db} / \mathrm{db}$ mice [119], yet endogenous FGF21 concentrations are positively associated with a range of dysmetabolic biomarkers, including blood glucose, insulin, and c-peptide concentrations in humans [120], which may reflect FGF21 resistance or other metabolic feedback processes. Nevertheless, despite its therapeutic potential, the FGF21 protein has rapid renal clearance [121], although the development of FGF21 analogues have helped circumvent this problem [122]. A phase I placebo-controlled clinical trial testing the effects of one such analogue (LY2405319) improved blood lipids and reduced body weight and fasting insulin, but showed no marked impact on blood glucose concentrations [123]. An alternative therapeutic approach might focus on dietary interventions designed to limit sugarsweetened foods and beverages in carriers of susceptibility variants at FGF21. However, the extent to which each risk allele is associated with increased sugar consumption is negligible at an individual level [115], and is unlikely to be of any value for targeted dietary interventions in clinical practice.

There are many studies exploring interactions between gene variants and diet or exercise in T2D (see [124]), yet most are relatively small, some are cross-sectional, and few findings have been replicated. The largest, most comprehensive epidemiological analysis was performed by the InterAct consortium [107], where interactions between 58 established T2D variants and lifestyle factors were assessed in a nested case-cohort comprised of 12,403 incident cases of diabetes and 16,154 nondiabetics. In analyses focused on a gene-score, no statistically significant interactions were observed with physical activity or dietary habits assessed by a Mediterranean diet score; although several individual variants showed nominal evidence of gene-lifestyle interactions, none was significant after correction for multiple-testing. The largest and most comprehensive clinical trial analysis was performed in the DPP $(n=2843)$, which focused on a genetic risk score and its interactions with lifestyle intervention (vs. standard of care) [104]. There was no evidence of a gene-lifestyle interaction in diabetes incidence, but there was nominal evidence of an interaction in regression from impaired to normal glucose regulation. Follow-up analyses in the DPP trial, focusing on gene variants previously associated with insulin resistance, found that these did not influence the effects of lifestyle on insulin sensitivity after 1 year of intervention [125]. Overall, there is little robust evidence from epidemiological studies or clinical trials showing that variants previously associated with T2D or insulin resistance modify the effects of lifestyle in diabetes incidence.

\section{Variation in the Tre-2/BUB2/cdc 1 domain family (TBC1D) genes as examples of biologic candidate genes connecting lifestyle and $T 2 D$}

TBC1D1 and 4 encode Rab-GTPase-activating proteins that regulate muscle glucose transport and fatty acid oxidation in response to insulin and exercise (see [126]). Abundant animal data implicate coding variation at Tbc1d1 in exercise-related modulation of muscle glucose uptake and weight change, and in vitro perturbation of TBC1D1-transfected mouse myocytes by AICAR (an exercise mimetic) was shown to impact palmitate oxidation [127]; however, it remains unknown whether coding variation at TBC1D1 in humans influences glucose and lipid metabolism. Evidence in humans of how TBC1D4 variation impacts diabetes risk is more concrete. Homozygote carriers of the nonsense p.Arg684ter allele at $T B C 1 D 4$, common within the Greenlandic Inuit but rare elsewhere, have a roughly 10 -fold increased odds of T2D [128]. An exaggerated early insulin response was reported elsewhere in family members with acanthosis nigricans who carried a heterozygous substitution of thymine for cytosine at nucleotide position 1087 in exon 3, resulting in the substitution of a premature stop codon (TGA) for arginine (CGA) at codon 363 [129]. The mechanism appears to involve muscle-selective loss of the long isoform of TBC1D4, leading to a much reduced GLUT4-mediated insulin-stimulated glucose uptake into muscle and marked postprandial (but not fasting) hyperglycemia. What remains unknown is whether exerciseinduced AS160 phosphorylation (the protein encoded by TCB1D4) and GLUT4 translocation (a key feature of insulin-dependent and non-insulin-dependent glucose transportation regulated by AS160 phosphorylation) also differ by TBC1D4 genotypes in outbred populations and, if so, whether exercise might be sufficient to offset the 
impairments in GLUT4 sequestration attributable to TBC1D4 isoform restriction.

\section{Transcripts, proteins, and epigenetic marks}

The nuclear genome encodes biological processes that are necessary to maintain normal physiological function. The transcription and translation of genetic code can be perturbed by extrinsic and intrinsic environmental stimuli, and by chemical modifications of DNA (broadly termed 'epigenetics'). In some instances, it may be that diet and exercise interact with epigenetic features, such that the physiological consequences of a lifestyle exposure are determined in part by the presence or absence of an epigenetic mark; in other cases, it may be that diet and exercise causes an epigenetic mark to emerge or disappear.

There is extensive literature on the effects of exercise or diet interventions on biomarkers of gene transcription and translation. The transcription (mRNA production) and translation (protein synthesis) of metabolic regulator genes, particularly those involved in mitochondrial biogenesis and mitochondrial function (e.g., PPARGC1A, $A M P K$, and SIRT1), have long been the focus of diet and exercise studies, particularly in the context of energy flux and substrate metabolism (see [130]). Although there are many intervention studies designed to test whether perturbation by diet or exercise affects molecular processes, most are not RCTs; this is an important limitation, as the absence of a control arm makes it impossible to determine that the intervention's effects are not confounded by other unmeasured variables. This problem was highlighted in a study where many genes thought to be 'exercise-induced' were shown to change in both control and intervention arms, i.e., effects were not specific to exercise [131].

Most evidence linking lifestyle with changes in gene expression and epigenetic marks originates from crosssectional cohorts. By contrast, RCTs focused on these issues are exceptionally rare. One of the few RCTs within which the effects of diet on metabolites and methylation marks have been studied is the LIPOGAIN trial [132]. In this double-blind, randomized, parallel-arm intervention trial, young adults $(21-38$ years; $n=41)$ were randomized to receive one of two types of high-energy content muffins, supplemental to their habitual diet, for 7 weeks; muffins contained either refined palm oil (rich in the major SFA palmitic acid (16:0)) or refined sunflower oil (rich in the major PUFA linoleic acid (18:2 n-6)). Abdominal subcutaneous adipose tissue was biopsied before and after the dietary intervention, liver fat was assessed using magnetic resonance imaging, and DNA and RNA were extracted for genome-wide methylation and mRNA analyses, respectively. Analysis of 37 of the 41 randomized participants explored changes in gene expression. Three genes, carbonic anhydrase 3 , connective tissue growth factor, and aldehyde dehydrogenase 1 family member A1, were determined to be differentially expressed over time and between intervention arms. In a second report from a subset of the LIPOGAIN study $(n=31)$ [133], multiple changes in DNA methylation of individual genes and $\mathrm{CpG}$ sites were reported when focusing on both intervention arms combined or separately within intervention arms. In the within-arm analyses controlling for changes in cell composition and multiple testing, methylation levels changed at 309 sites within the SFA-rich muffin arm and at 4662 sites in the PUFA-rich muffin arm. However, whether expression and methylation were of greater or lesser magnitude between intervention arms was not reported, and there was no control arm.

\section{Metabolites}

Metabolites are intermediary compounds produced by naturally occurring enzyme-catalyzed reactions within cells, bearing the parent compound's characteristics until fully degraded, and generated to control the rate of energy turnover and to perform other functions within cells. The measurement of metabolites in the body (usually in blood or urine) provides a read-out of specific metabolic processes. Examples of metabolites include amino acids within proteins, glucose molecules in glycogen, fatty acids within membrane lipids, and nucleotides in DNA [134].

Metabolomic profiling of diet and exercise signatures has yielded potentially useful tools to objectively assess these traits. For example, differential metabolomic profiles were determined using nuclear magnetic resonance spectroscopy in an observational study of twins discordant for physical activity, such that one twin of each pair reported no structured leisure-time physical activity, whereas the other reported more than 5 years regular leisure-time physical activity [135]. Twins who reported being physically active had lower serum concentrations of isoleucine, $\alpha 1$-acid glycoprotein, and glucose; moreover, the fatty acid profile was less saturated. In the INTERMAP UK cohort [136], 'diet discriminative' metabolomic profiles were generated within a randomized cross-over diet intervention trial by profiling urine samples taken following each 72-h diet intervention using proton nuclear magnetic resonance spectroscopy. In both studies, physical activity and diet profiles were validated by demonstrating associations between metabolomic signatures and disease outcomes known to be associated with diet and physical inactivity.

\section{Microbiota}

The human microbiota is comprised of four microorganisms (bacteria, fungi, archaea, and viruses) that live in or on the body and serve multiple essential functions [137]. The 'microbiome' is the genetic material derived 
from all four micro-organisms taken from a given microbial ecosystem.

In a study of 800 young adults, Zeevi et al. [138] assessed glycemic responses to almost 50,000 meals. They found high between-participant variability in response and, using machine learning methods, they were able to derive and validate a prediction algorithm that harnessed data on the intestinal microbiome; they later designed personalized diet interventions and showed that these could be used to regulate glycemic excursions following meals and robust changes in the configuration of gut microbiota.

\section{Conclusions}

Precision medicine research generally seeks to (1) elucidate the biology for the development of therapeutic targets or (2) identify biomarkers that can be used to inform health decisions and/or design new therapeutic strategies. In the latter, there are multiple contexts of use where biomarkers might play a key role in optimizing the design, timing, or delivery of lifestyle interventions (see [100]).

Determining whether discoveries in lifestyle precision medicine are likely to be of eventual clinical value first requires that the translational avenue be identified. In the development of anti-diabetic drugs, genetics has proven extremely valuable for the discovery of novel targets, reducing costs and improving drug development pipelines [139]. There are excellent examples where genetic screening is routinely undertaken for rare genetic disorders, such as phenylketonuria, where mutation carriers are prescribed special diets, or where genetics can provide insight into allergies or intolerances to specific foods or nutrients [140]. However, in T2D, genetics or other omic biomarkers are yet to meaningfully impact the optimization of lifestyle therapies, although two recent studies that used machine learning algorithms to interrogate complex data structures to predict individual response to foods $[138,141]$ highlight the possibilities ahead. There are numerous promising biomarkers that might eventually prove useful in this regard, as discussed above, but this requires the careful qualification of the biomarker in its proposed context of use.

For example, to predict the rate of T2D diagnosis, a biomarker's predictive accuracy will need to be assessed, i.e., it should improve the accuracy of current prediction algorithms or enhance the reclassification of incident disease prediction. If the biomarker is to predict treatment response or side-effects, the assessment should be made in the context of an appropriately designed intervention study. The cost-effectiveness of lifestyle precision medicine strategies will also need to be demonstrated, as will the safety and scalability of such approaches. To date, no comprehensive attempts to do so in relation to biomarkers, lifestyle, and T2D have been described.

Curbing the global diabetes epidemic requires innovative approaches for its prevention. With the rapid development of biomarker technologies to characterize the etiology and pathogenesis of diabetes at scale, there are many ways in which lifestyle interventions could be optimized to help prevent T2D. However, major barriers to this vision include the assimilation and analysis of relevant, multi-omic biomarker data in specially designed lifestyle intervention trials. The analytical aspects alone are enormously challenging, as human biology is both complex and dynamic, but solutions are emerging [142]. The design and conduct of lifestyle trials for precision medicine also require innovative approaches to overcome the sources of bias and confounding that are difficult to circumvent when interventions cannot be masked. Nevertheless, recent advances in wearable technologies may help address these longstanding problems.

\section{Additional file}

Additional file 1: Table S1. Studies used in the review and their main findings. (DOCX $40 \mathrm{~kb}$ )

\section{Acknowledgements}

Not applicable.

\section{Funding}

The authors acknowledge funding for their research related to this paper from the Swedish Heart-Lung Foundation, the Novo Nordisk Foundation, the Swedish Research Council, the European Research Council (CoG-2015_681742_NASCENT) and the Innovative Medicines Initiative (DIRECT: grant agreement \#115317; RHAPSODY: grant agreement \#115881).

Availability of data and materials

Not applicable.

\section{Authors' contributions}

PM, GG and PF devised the review strategy and developed the search string PM performed the initial review of literature, and PF and GG reviewed and revised the data accordingly. All authors contributed in the writing of the manuscript and read and approved the final version.

\section{Authors' information}

GG is a dental surgeon and public health epidemiologist, currently employed as a researcher at Lund University Diabetes Centre. PM is a medical doctor and public health epidemiologist currently working as a doctoral student at Lund University Diabetes Centre. PF is a professor in genetic epidemiology and deputy-director of Lund University Diabetes Centre. His research has focused on the interplay of genetic and lifestyle factors in the development of obesity, type 2 diabetes, and cardiovascular disease.

Ethics approval and consent to participate Not applicable.

Consent for publication

Not applicable.

Competing interests

The authors declare that they have no competing interests. 


\section{Author details}

Department of Clinical Sciences, Genetic and Molecular Epidemiology Unit, Lund University, Skåne University Hospital, SE-205 02 Malmö, Sweden. 2Department of Public Health \& Clinical Medicine, Umeå University, Umeå, Sweden. ${ }^{3}$ Department of Nutrition, Harvard School of Public Health, Boston, MA, USA. ${ }^{4}$ Oxford Center for Diabetes, Endocrinology \& Metabolism, Radcliff Department of Medicine, University of Oxford, Oxford, UK.

Received: 10 May 2017 Accepted: 30 August 2017

Published online: 22 September 2017

\section{References}

1. Diabetes Atlas, International Diabetes Federation. 2017. http://www. diabetesatlas.org/atlas/atlas.html. Accessed 17 July 2017.

2. Tabak AG, Herder C, Rathmann W, Brunner EJ, Kivimaki M. Prediabetes: a high-risk state for diabetes development. Lancet. 2012;379(9833):2279-90.

3. Diabetes Prevention Program Research Group. Within-trial cost-effectiveness of lifestyle intervention or metformin for the primary prevention of type 2 diabetes. Diabetes Care. 2003;26(9):2518-23.

4. Taylor R. Type 2 diabetes: etiology and reversibility. Diabetes Care. 2013;36(4):1047-55.

5. Yates T, Khunti K, Bull F, Gorely T, Davies MJ. The role of physical activity in the management of impaired glucose tolerance: a systematic review. Diabetologia. 2007;50(6):1116-26.

6. Knowler WC, Fowler SE, Hamman RF, Christophi CA, Hoffman HJ, Brenneman AT, Brown-Friday JO, Goldberg R, Venditti E, Nathan DM. 10year follow-up of diabetes incidence and weight loss in the Diabetes Prevention Program Outcomes Study. Lancet. 2009;374(9702):1677-86.

7. Poveda A, Chen Y, Brandstrom A, Engberg E, Hallmans G, Johansson I, Renstrom F, Kurbasic A, Franks PW. The heritable basis of gene-environment interactions in cardiometabolic traits. Diabetologia. 2017;60(3):442-52.

8. Bohm A, Weigert C, Staiger $\mathrm{H}$, Haring HU. Exercise and diabetes: relevance and causes for response variability. Endocrine. 2016;51(3):390-401.

9. Belluz J. "Personalized nutrition" isn't going to solve our diet problems. Vox Media Online. United States: Vox Media Inc.; 2017. https://www.vox.com/ 2016/11/2/13453434/personalized-diet-nutrition-dna. Accessed 26 May 2017.

10. IDF Diabetes Atlas. 7 edn. Brussels: International Diabetes Federation; 2015.

11. World Health Organization. Global Report on Diabetes, 2016. Geneva: WHO; 2016

12. Hu FB, Manson JE, Stampfer MJ, Colditz G, Liu S, Solomon CG, Willett WC. Diet, lifestyle, and the risk of type 2 diabetes mellitus in women. $\mathrm{N}$ Engl J Med. 2001;345(11):790-7.

13. Chen CC, Liu K, Hsu CC, Chang HY, Chung HC, Liu JS, Liu YH, Tsai TL, Liaw WJ, Lin IC, et al. Healthy lifestyle and normal waist circumference are associated with a lower 5-year risk of type 2 diabetes in middle-aged and elderly individuals: Results from the healthy aging longitudinal study in Taiwan (HALST). Medicine. 2017;96(6), e6025.

14. Schmitz N, Deschenes S, Burns R, Smith KJ. Depressive symptoms and glycated hemoglobin A1c: a reciprocal relationship in a prospective cohort study. Psychol Med. 2016;46(5):945-55

15. Liu X, Shi J, Wang A, Song Q, Huang Z, Zhu C, Du X, Zhang Y, Chen S, Wang X et al. Changes in ideal cardiovascular health status and risk of new-onset type 2 diabetes: The Kailuan prospective study. Medicine. 2016;95(34), e4571.

16. Liu B, Feng W, Wang J, Li Y, Han X, Hu H, Guo H, Zhang X, He M. Association of urinary metals levels with type 2 diabetes risk in coke oven workers. Environ Pollut. 2016;210:1-8.

17. Hublin C, Lehtovirta M, Partinen M, Koskenvuo M, Kaprio J. Napping and the risk of type 2 diabetes: a population-based prospective study. Sleep Med. 2016;17:144-8.

18. Weinmayr G, Hennig F, Fuks K, Nonnemacher M, Jakobs H, Mohlenkamp S, Erbel R, Jockel KH, Hoffmann B, Moebus S. Long-term exposure to fine particulate matter and incidence of type 2 diabetes mellitus in a cohort study: effects of total and traffic-specific air pollution. Environ Health. 2015;14:53.

19. Suarez-Lopez JR, Lee DH, Porta M, Steffes MW, Jacobs Jr DR. Persistent organic pollutants in young adults and changes in glucose related metabolism over a 23-year follow-up. Environ Res. 2015:137:485-94.

20. Schmiedel K, Mayr A, Fiessler C, Schlager H, Friedland K. Effects of the lifestyle intervention program GLICEMIA in people at risk for type 2 diabetes: a clusterrandomized controlled trial. Diabetes Care. 2015;38(5):937-9.
21. Park SK, Adar SD, O'Neill MS, Auchincloss AH, Szpiro A, Bertoni AG, NavasAcien A, Kaufman JD, Diez-Roux AV. Long-term exposure to air pollution and type 2 diabetes mellitus in a multiethnic cohort. Am J Epidemiol. 2015;181(5):327-36.

22. Masters Pedersen J, Hulvej Rod N, Andersen I, Lange T, Poulsen G, Prescott E, Lund R. Accumulation of major life events in childhood and adult life and risk of type 2 diabetes mellitus. PLoS One. 2015;10(9), e0138654.

23. Li Y, Ley SH, Tobias DK, Chiuve SE, VanderWeele TJ, Rich-Edwards JW, Curhan GC, Willett WC, Manson JE, Hu FB, et al. Birth weight and later life adherence to unhealthy lifestyles in predicting type 2 diabetes: prospective cohort study. BMJ. 2015;351:h3672.

24. Kuo CC, Howard BV, Umans JG, Gribble MO, Best LG, Francesconi KA, Goessler W, Lee E, Guallar E, Navas-Acien A. Arsenic exposure, arsenic metabolism, and incident diabetes in the strong heart study. Diabetes Care. 2015:38(4):620-7.

25. Aroda VR, Christophi CA, Edelstein SL, Zhang P, Herman WH, Barrett-Connor E, Delahanty LM, Montez MG, Ackermann RT, Zhuo X, et al. The effect of lifestyle intervention and metformin on preventing or delaying diabetes among women with and without gestational diabetes: the Diabetes Prevention Program outcomes study 10-year follow-up. J Clin Endocrinol Metab. 2015;100(4):1646-53.

26. InterAct Consortium. Dietary fibre and incidence of type 2 diabetes in eight European countries: the EPIC-InterAct Study and a meta-analysis of prospective studies. Diabetologia. 2015;58(7):1394-408.

27. Diabetes Prevention Program Research Group, Nathan DM, Barrett-Connor E Crandall JP, Edelstein SL, Goldberg RB, Horton ES, Knowler WC, Mather KJ, Orchard TJ, Pi-Sunyer X, Schade D, Temprosa M. Long-term effects of lifestyle intervention or metformin on diabetes development and microvascular complications over 15-year follow-up: the Diabetes Prevention Program Outcomes Study. Lancet Diabet Endocrinol. 2015;3(11):866-75.

28. Smith L, Hamer M. Television viewing time and risk of incident diabetes mellitus: the English Longitudinal Study of Ageing. Diabetic Med. 2014;31(12):1572-6.

29. Ram J, Selvam S, Snehalatha C, Nanditha A, Simon M, Shetty AS, Godsland IF, Johnston DG, Ramachandran A. Improvement in diet habits, independent of physical activity helps to reduce incident diabetes among prediabetic Asian Indian men. Diabetes Res Clin Pract. 2014;106(3):491-5.

30. Mehlig K, Skoog I, Waern M, Miao Jonasson J, Lapidus L, Bjorkelund C, Ostling S, Lissner L. Physical activity, weight status, diabetes and dementia: a 34-year follow-up of the population study of women in Gothenburg. Neuroepidemiology. 2014;42(4):252-9.

31. Manini TM, Lamonte MJ, Seguin RA, Manson JE, Hingle M, Garcia L, Stefanick ML, Rodriguez B, Sims S, Song Y, et al. Modifying effect of obesity on the association between sitting and incident diabetes in postmenopausal women. Obesity. 2014;22(4):1133-41.

32. Koloverou E, Panagiotakos DB, Pitsavos C, Chrysohoou C, Georgousopoulou EN, Pitaraki E, Metaxa V, Stefanadis C. 10-year incidence of diabetes and associated risk factors in Greece: the ATTICA study (2002-2012). Rev Diabet Stud. 2014;11(2):181-9.

33. Heidemann C, Niemann H, Paprott R, Du Y, Rathmann W, Scheidt-Nave C. Residential traffic and incidence of type 2 diabetes: the German Health Interview and Examination Surveys. Diabetic Med. 2014:31(10):1269-76.

34. Eze IC, Schaffner E, Fischer E, Schikowski T, Adam M, Imboden M, Tsai M, Carballo D, von Eckardstein A, Kunzli N, et al. Long-term air pollution exposure and diabetes in a population-based Swiss cohort. Environ Int. 2014;70:95-105.

35. Borne Y, Fagerberg B, Persson M, Sallsten G, Forsgard N, Hedblad B, Barregard L, Engstrom G. Cadmium exposure and incidence of diabetes mellitus-results from the Malmo Diet and Cancer study. PLoS One. 2014:9(11), e112277.

36. Tatsumi Y, Ohno Y, Morimoto A, Nishigaki Y, Mizuno S, Watanabe S. Lifestyle and the risk of diabetes mellitus in a Japanese population. J Behav Med. 2013;36(3):225-33

37. Struijk EA, Heraclides A, Witte DR, Soedamah-Muthu SS, Geleijnse JM, Toft U, Lau CJ. Dairy product intake in relation to glucose regulation indices and risk of type 2 diabetes. Nutr Metab Cardiovasc Dis. 2013;23(9):822-8.

38. Soedamah-Muthu SS, Masset G, Verberne L, Geleijnse JM, Brunner EJ. Consumption of dairy products and associations with incident diabetes, CHD and mortality in the Whitehall II study. Br J Nutr. 2013;109(4):718-26.

39. Rolando L, Byrne DW, McGown PW, Goetzel RZ, Elasy TA, Yarbrough MI. Health risk factor modification predicts incidence of diabetes in an employee population: results of an 8-year longitudinal cohort study. J Occup Environ Med. 2013;55(4):410-5. 
40. Lim S, Kim KM, Kim MJ, Woo SJ, Choi SH, Park KS, Jang HC, Meigs JB, Wexler DJ. The association of maximum body weight on the development of type 2 diabetes and microvascular complications: MAXWEL study. PLoS One. 2013;8(12), e80525.

41. Djousse L, Driver JA, Gaziano JM, Buring JE, Lee IM. Association between modifiable lifestyle factors and residual lifetime risk of diabetes. Nutr Metab Cardiovasc Dis. 2013;23(1):17-22.

42. Chen H, Burnett RT, Kwong JC, Villeneuve PJ, Goldberg MS, Brook RD, van Donkelaar A, Jerrett M, Martin RV, Brook JR, et al. Risk of incident diabetes in relation to long-term exposure to fine particulate matter in Ontario, Canada. Environ Health Perspect. 2013;121(7):804-10

43. Bauer F, Beulens JW, van der AD, Wijmenga C, Grobbee DE, Spijkerman AM, van der Schouw YT, Onland-Moret NC. Dietary patterns and the risk of type 2 diabetes in overweight and obese individuals. Eur J Nutr. 2013;52(3):1127-34.

44. Barregard $L$, Bergstrom G, Fagerberg B. Cadmium exposure in relation to insulin production, insulin sensitivity and type 2 diabetes: a cross-sectional and prospective study in women. Environ Res. 2013;121:104-9.

45. Morimoto A, Ohno Y, Tatsumi Y, Mizuno S, Watanabe S. Effects of healthy dietary pattern and other lifestyle factors on incidence of diabetes in a rural Japanese population. Asia Pac J Clin Nutr. 2012;21(4):601-8.

46. Ekelund U, Palla L, Brage S, Franks PW, Peters T, Balkau B, Diaz MJ, Huerta JM, Agnoli C, Arriola L, et al. Physical activity reduces the risk of incident type 2 diabetes in general and in abdominally lean and obese men and women: the EPIC-InterAct Study. Diabetologia. 2012;55(7):1944-52.

47. Coogan PF, White LF, Jerrett M, Brook RD, Su JG, Seto E, Burnett R, Palmer JR, Rosenberg L. Air pollution and incidence of hypertension and diabetes mellitus in black women living in Los Angeles. Circulation. 2012;125(6):767-72.

48. Zhang Y, Lee ET, Cowan LD, Fabsitz RR, Howard BV. Coffee consumption and the incidence of type 2 diabetes in men and women with normal glucose tolerance: the Strong Heart Study. Nutr Metab Cardiovasc Dis. 2011;21(6):418-23.

49. Sakane N, Sato J, Tsushita K, Tsujii S, Kotani K, Tsuzaki K, Tominaga M, Kawazu S, Sato $Y$, Usui T, et al. Prevention of type 2 diabetes in a primary healthcare setting: three-year results of lifestyle intervention in Japanese subjects with impaired glucose tolerance. BMC Public Health. 2011;11:40.

50. Romaguera D, Guevara M, Norat T, Langenberg C, Forouhi NG, Sharp S, Slimani N, Schulze MB, Buijsse B, Buckland G, et al. Mediterranean diet and type 2 diabetes risk in the European Prospective Investigation into Cancer and Nutrition (EPIC) study: the InterAct project. Diabetes Care. 2011;34(9):1913-8.

51. Puett RC, Hart JE, Schwartz J, Hu FB, Liese AD, Laden F. Are particulate matter exposures associated with risk of type 2 diabetes? Environ Health Perspect. 2011;119(3):384-9.

52. Ponsonby AL, Sun C, Ukoumunne OC, Pezic A, Venn A, Shaw JE, Dunstan DW, Barr EL, Blair SN, Cochrane J, et al. Objectively measured physical activity and the subsequent risk of incident dysglycemia: the Australian Diabetes, Obesity and Lifestyle Study (AusDiab). Diabetes Care. 2011;34(7): 1497-502.

53. Ko KP, Min H, Ahn Y, Park SJ, Kim CS, Park JK, Kim SS. A prospective study investigating the association between environmental tobacco smoke exposure and the incidence of type 2 diabetes in never smokers. Ann Epidemiol. 2011;21(1):42-7.

54. Joosten MM, Chiuve SE, Mukamal KJ, Hu FB, Hendriks HF, Rimm EB. Changes in alcohol consumption and subsequent risk of type 2 diabetes in men. Diabetes. 2011;60(1):74-9.

55. Waller K, Kaprio J, Lehtovirta M, Silventoinen K, Koskenvuo M, Kujala UM Leisure-time physical activity and type 2 diabetes during a 28 year followup in twins. Diabetologia. 2010;53(12):2531-7.

56. Kowall B, Rathmann W, Strassburger K, Heier M, Holle R, Thorand B, Giani G, Peters A, Meisinger C. Association of passive and active smoking with incident type 2 diabetes mellitus in the elderly population: the KORA S4/F4 cohort study. Eur J Epidemiol. 2010;25(6):393-402.

57. Joosten MM, Grobbee DE, van der AD, Verschuren WM, Hendriks HF, Beulens JW. Combined effect of alcohol consumption and lifestyle behaviors on risk of type 2 diabetes. Am J Clin Nutr. 2010;91(6):1777-83.

58. Harati $H$, Hadaegh F, Momenan AA, Ghanei L, Bozorgmanesh MR, Ghanbarian A, Mirmiran P, Azizi F. Reduction in incidence of type 2 diabetes by lifestyle intervention in a middle eastern community. Am J Prevent Med. 2010;38(6):628-36.e621.

59. Ford ES, Schulze MB, Kroger J, Pischon T, Bergmann MM, Boeing $H$. Television watching and incident diabetes: findings from the European Prospective Investigation into Cancer and Nutrition-Potsdam Study. J Diabetes. 2010;2(1):23-7.
60. Tuomilehto H, Peltonen M, Partinen M, Lavigne G, Eriksson JG, Herder C, Aunola S, Keinanen-Kiukaanniemi S, Ilanne-Parikka P, Uusitupa M, et al. Sleep duration, lifestyle intervention, and incidence of type 2 diabetes in impaired glucose tolerance: The Finnish Diabetes Prevention Study. Diabetes Care. 2009;32(11):1965-71.

61. Rignell-Hydbom A, Lidfeldt J, Kiviranta H, Rantakokko P, Samsioe G, Agardh CD, Rylander L. Exposure to p, p'-DDE: a risk factor for type 2 diabetes. PLoS One. 2009;4(10), e7503.

62. Krishnan S, Rosenberg L, Palmer JR. Physical activity and television watching in relation to risk of type 2 diabetes: the Black Women's Health Study. Am J Epidemiol. 2009;169(4):428-34.

63. Kirii K, Mizoue T, Iso H, Takahashi Y, Kato M, Inoue M, Noda M, Tsugane S. Calcium, vitamin $\mathrm{D}$ and dairy intake in relation to type 2 diabetes risk in a Japanese cohort. Diabetologia. 2009;52(12):2542-50.

64. Fretts AM, Howard BV, Kriska AM, Smith NL, Lumley T, Lee ET, Russell M, Siscovick D. Physical activity and incident diabetes in American Indians: the Strong Heart Study. Am J Epidemiol. 2009;170(5):632-9.

65. Vang A, Singh PN, Lee JW, Haddad EH, Brinegar CH. Meats, processed meats, obesity, weight gain and occurrence of diabetes among adults: findings from Adventist Health Studies. Ann Nutr Metab. 2008:52(2):96-104.

66. Nettleton JA, Steffen LM, Ni H, Liu K, Jacobs Jr DR. Dietary patterns and risk of incident type 2 diabetes in the Multi-Ethnic Study of Atherosclerosis (MESA). Diabetes Care. 2008;31(9):1777-82

67. Montgomery MP, Kamel F, Saldana TM, Alavanja MC, Sandler DP. Incident diabetes and pesticide exposure among licensed pesticide applicators: Agricultural Health Study, 1993-2003. Am J Epidemiol. 2008;167(10):1235-46.

68. Li G, Zhang P, Wang J, Gregg EW, Yang W, Gong Q, Li H, Li H, Jiang Y, An Y, et al. The long-term effect of lifestyle interventions to prevent diabetes in the China Da Qing Diabetes Prevention Study: a 20-year follow-up study. Lancet. 2008;371(9626):1783-9.

69. Hamer M, Witte DR, Mosdol A, Marmot MG, Brunner EJ. Prospective study of coffee and tea consumption in relation to risk of type 2 diabetes mellitus among men and women: the Whitehall II study. Br J Nutr. 2008;100(5):1046-53.

70. Kroenke CH, Spiegelman D, Manson J, Schernhammer ES, Colditz GA, Kawachi I. Work characteristics and incidence of type 2 diabetes in women. Am J Epidemiol. 2007;165(2):175-83.

71. Vasiliu O, Cameron L, Gardiner J, Deguire P, Karmaus W. Polybrominated biphenyls, polychlorinated biphenyls, body weight, and incidence of adultonset diabetes mellitus. Epidemiology. 2006;17(4):352-9.

72. Schienkiewitz A, Schulze MB, Hoffmann K, Kroke A, Boeing H. Body mass index history and risk of type 2 diabetes: results from the European Prospective Investigation into Cancer and Nutrition (EPIC)-Potsdam Study. Am J Clin Nutr. 2006;84(2):427-33.

73. Ramachandran A, Snehalatha C, Mary S, Mukesh B, Bhaskar AD, Vijay V. The Indian Diabetes Prevention Programme shows that lifestyle modification and metformin prevent type 2 diabetes in Asian Indian subjects with impaired glucose tolerance (IDPP-1). Diabetologia. 2006;49(2):289-97.

74. Choi HK, Willett WC, Stampfer MJ, Rimm E, Hu FB. Dairy consumption and risk of type 2 diabetes mellitus in men: a prospective study. Arch Intern Med. 2005;165(9):997-1003

75. Song Y, Manson JE, Buring JE, Liu S. A prospective study of red meat consumption and type 2 diabetes in middle-aged and elderly women: the women's health study. Diabetes Care. 2004;27(9):2108-15.

76. Lindstrom J, Eriksson JG, Valle TT, Aunola S, Cepaitis Z, Hakumaki M, Hamalainen H, Ilanne-Parikka P, Keinanen-Kiukaanniemi S, Laakso M, et al. Prevention of diabetes mellitus in subjects with impaired glucose tolerance in the Finnish Diabetes Prevention Study: results from a randomized clinical trial. J Am Soc Nephrol. 2003;14(7 Suppl 2):S108-13.

77. Kriska AM, Saremi A, Hanson RL, Bennett PH, Kobes S, Williams DE, Knowler WC. Physical activity, obesity, and the incidence of type 2 diabetes in a high-risk population. Am J Epidemiol. 2003;158(7):669-75.

78. Hu FB, Li TY, Colditz GA, Willett WC, Manson JE. Television watching and other sedentary behaviors in relation to risk of obesity and type 2 diabetes mellitus in women. JAMA. 2003;289(14):1785-91.

79. Knowler WC, Barrett-Connor E, Fowler SE, Hamman RF, Lachin JM, Walker EA, Nathan DM. Reduction in the incidence of type 2 diabetes with lifestyle intervention or metformin. N Engl J Med. 2002;346(6):393-403.

80. Hu FB, Leitzmann MF, Stampfer MJ, Colditz GA, Willett WC, Rimm EB. Physical activity and television watching in relation to risk for type 2 diabetes mellitus in men. Arch Intern Med. 2001;161(12):1542-8. 
81. Tseng CH, Tai TY, Chong CK, Tseng CP, Lai MS, Lin BJ, Chiou HY, Hsueh YM, $\mathrm{Hsu} \mathrm{KH}$, Chen CJ. Long-term arsenic exposure and incidence of non-insulindependent diabetes mellitus: a cohort study in arseniasis-hyperendemic villages in Taiwan. Environ Health Perspect. 2000;108(9):847-51.

82. Rich-Edwards JW, Colditz GA, Stampfer MJ, Willett WC, Gillman MW, Hennekens $\mathrm{CH}$, Speizer FE, Manson JE. Birthweight and the risk for type 2 diabetes mellitus in adult women. Ann Intern Med. 1999;130(4 Pt 1):278-84.

83. Kawakami N, Araki S, Takatsuka N, Shimizu H, Ishibashi H. Overtime, psychosocial working conditions, and occurrence of non-insulin dependent diabetes mellitus in Japanese men. J Epidemiol Commun Health. 1999;53(6):359-63.

84. Pan XR, Li GW, Hu YH, Wang JX, Yang WY, An ZX, Hu ZX, Lin J, Xiao JZ, Cao $H B$, et al. Effects of diet and exercise in preventing NIDDM in people with impaired glucose tolerance. The Da Qing IGT and Diabetes Study. Diabetes Care. 1997;20(4):537-44.

85. Monterrosa AE, Haffner SM, Stern MP, Hazuda HP. Sex difference in lifestyle factors predictive of diabetes in Mexican-Americans. Diabetes Care. 1995; 18(4):448-56.

86. Lindstrom J, Louheranta A, Mannelin M, Rastas M, Salminen V, Eriksson J, Uusitupa M, Tuomilehto J. The Finnish Diabetes Prevention Study (DPS): Lifestyle intervention and 3-year results on diet and physical activity. Diabetes Care. 2003;26(12):3230-6.

87. Lindstrom J, Peltonen M, Eriksson JG, llanne-Parikka P, Aunola S, KeinanenKiukaanniemi S, Uusitupa M, Tuomilehto J. Improved lifestyle and decreased diabetes risk over 13 years: long-term follow-up of the randomised Finnish Diabetes Prevention Study (DPS). Diabetologia. 2013;56(2):284-93.

88. Slentz CA, Bateman LA, Willis LH, Granville EO, Piner LW, Samsa GP, Setji TL, Muehlbauer MJ, Huffman KM, Bales CW, et al. Effects of exercise training alone vs a combined exercise and nutritional lifestyle intervention on glucose homeostasis in prediabetic individuals: a randomised controlled trial. Diabetologia. 2016;59(10):2088-98.

89. Salas-Salvado J, Bullo M, Babio N, Martinez-Gonzalez MA, Ibarrola-Jurado N, Basora $J$, Estruch R, Covas Ml, Corella D, Aros F, et al. Reduction in the incidence of type 2 diabetes with the Mediterranean diet: results of the PREDIMED-Reus nutrition intervention randomized trial. Diabetes Care. 2011;34(1):14-9.

90. Christine PJ, Auchincloss AH, Bertoni AG, Carnethon MR, Sanchez BN, Moore K, Adar SD, Horwich TB, Watson KE, Diez Roux AV. Longitudinal associations between neighborhood physical and social environments and incident type 2 diabetes mellitus: the Multi-Ethnic Study of Atherosclerosis (MESA). JAMA Intern Med. 2015;175(8):1311-20.

91. Dinescu D, Horn EE, Duncan G, Turkheimer E. Socioeconomic modifiers of genetic and environmental influences on body mass index in adult twins. Health Psychol. 2016;35(2):157-66.

92. Tyrrell J, Wood AR, Ames RM, Yaghootkar H, Beaumont RN, Jones SE, Tuke MA, Ruth KS, Freathy RM, Davey Smith G, et al. Gene-obesogenic environment interactions in the UK Biobank study. Int J Epidemiol. 2017:46(2):559-75.

93. Wardle J, Carnell S, Haworth CM, Plomin R. Evidence for a strong genetic influence on childhood adiposity despite the force of the obesogenic environment. Am J Clin Nutr. 2008;87(2):398-404.

94. Hemani G, Yang J, Vinkhuyzen A, Powell JE, Willemsen G, Hottenga JJ, Abdellaoui A, Mangino M, Valdes AM, Medland SE, et al. Inference of the genetic architecture underlying BMI and height with the use of 20,240 sibling pairs. Am J Human Genet. 2013;93(5):865-75.

95. Ahmad S, Rukh G, Varga TV, Ali A, Kurbasic A, Shungin D, Ericson U, Koivula RW, Chu AY, Rose LM, et al. Gene x physical activity interactions in obesity: combined analysis of 111,421 individuals of European ancestry. PLoS Genet. 2013;9(7), e1003607.

96. Abraham G, Inouye M. Fast principal component analysis of large-scale genome-wide data. PLoS One. 2014;9(4), e93766.

97. Talaei Pashiri M, Huang T, Koh W-P. Abstract P206: coffee intake was not causally associated with type 2 diabetes risk in Asians: a Mendelian randomization based on the Singapore Chinese Health Study. Circulation. 2017;135 Suppl 1:AP206

98. Nordestgaard AT, Thomsen M, Nordestgaard BG. Coffee intake and risk of obesity, metabolic syndrome and type 2 diabetes: a Mendelian randomization study. Int J Epidemiol. 2015;44(2):551-65.

99. Kuijsten A, et al. Dietary fibre and incidence of type 2 diabetes in eight European countries: the EPIC-InterAct Study and a meta-analysis of prospective studies. Diabetologia. 2015;58(7):1394-408.

100. Franks PW, Poveda A. Lifestyle and precision diabetes medicine: will genomics help optimise the prediction, prevention and treatment of type 2 diabetes through lifestyle therapy? Diabetologia. 2017;60(5):784-92.
101. Corella D, Asensio EM, Coltell O, Sorli JV, Estruch R, Martinez-Gonzalez MA, Salas-Salvado J, Castaner O, Aros F, Lapetra J, et al. CLOCK gene variation is associated with incidence of type-2 diabetes and cardiovascular diseases in type-2 diabetic subjects: dietary modulation in the PREDIMED randomized trial. Cardiovasc Diabetol. 2016;15:4.

102. Billings LK, Jablonski KA, Warner AS, Cheng YC, McAteer JB, Tipton L, Shuldiner AR, Ehrmann DA, Manning AK, Dabelea D, et al. Variation in maturity-onset diabetes of the young genes influence response to interventions for diabetes prevention. J Clin Endocrinol Metabol. 2017;102(8):2678-89.

103. Florez JC, Jablonski KA, Bayley N, Pollin TI, de Bakker PI, Shuldiner AR, Knowler WC, Nathan DM, Altshuler D. TCF7L2 polymorphisms and progression to diabetes in the Diabetes Prevention Program. N Engl J Med. 2006:355(3):241-50.

104. Hivert MF, Jablonski KA, Perreault L, Saxena R, McAteer JB, Franks PW, Hamman RF, Kahn SE, Haffner S, Meigs JB, et al. Updated genetic score based on 34 confirmed type 2 diabetes Loci is associated with diabetes incidence and regression to normoglycemia in the diabetes prevention program. Diabetes. 2011;60(4):1340-8.

105. Jablonski KA, McAteer JB, de Bakker PI, Franks PW, Pollin TI, Hanson RL, Saxena R, Fowler S, Shuldiner AR, Knowler WC, et al. Common variants in 40 genes assessed for diabetes incidence and response to metformin and lifestyle intervention in the diabetes prevention program. Diabetes. 2010;59(10):2672-81.

106. Kilpelainen TO, Lakka TA, Laaksonen DE, Mager U, Salopuro T, Kubaszek A, Todorova B, Laukkanen O, Lindstrom J, Eriksson JG, et al. Interaction of single nucleotide polymorphisms in ADRB2, ADRB3, TNF, IL6, IGF1R, LIPC, LEPR, and GHRL with physical activity on the risk of type 2 diabetes mellitus and changes in characteristics of the metabolic syndrome: The Finnish Diabetes Prevention Study. Metabolism. 2008;57(3):428-36.

107. Langenberg C, Sharp SJ, Franks PW, Scott RA, Deloukas P, Forouhi NG, Froguel P, Groop LC, Hansen T, Palla L, et al. Gene-lifestyle interaction and type 2 diabetes: the EPIC interact case-cohort study. PLoS Med. 2014;11(5), e1001647.

108. Fisher E, Boeing H, Fritsche A, Doering F, Joost HG, Schulze MB. Whole-grain consumption and transcription factor-7-like 2 ( TCF7L2) rs7903146: genediet interaction in modulating type 2 diabetes risk. Br J Nutr. 2009;101(4): 478-81.

109. Hindy G, Sonestedt E, Ericson U, Jing XJ, Zhou Y, Hansson O, Renstrom E, Wirfalt E, Orho-Melander M. Role of TCF7L2 risk variant and dietary fibre intake on incident type 2 diabetes. Diabetologia. 2012;55(10):2646-54.

110. InterAct Consortium. Investigation of gene-diet interactions in the incretin system and risk of type 2 diabetes: the EPIC-InterAct study. Diabetologia. 2016:59(12):2613-21.

111. Brito EC, Lyssenko V, Renstrom F, Berglund G, Nilsson PM, Groop L, Franks PW. Previously associated type 2 diabetes variants may interact with physical activity to modify the risk of impaired glucose regulation and type 2 diabetes: a study of 16,003 Swedish adults. Diabetes. 2009;58(6):1411-8.

112. Qi Q, Kilpelainen TO, Downer MK, Tanaka T, Smith CE, Sluijs I, Sonestedt E, Chu AY, Renstrom F, Lin X, et al. FTO genetic variants, dietary intake and body mass index: insights from 177,330 individuals. Human Molec Genet. 2014;23(25):6961-72.

113. Cecil JE, Tavendale R, Watt P, Hetherington MM, Palmer CN. An obesityassociated FTO gene variant and increased energy intake in children. N Engl J Med. 2008;359(24):2558-66.

114. Kharitonenkov A, Shiyanova $T L$, Koester A, Ford AM, Micanovic R, Galbreath EJ, Sandusky GE, Hammond LJ, Moyers JS, Owens RA, et al. FGF-21 as a novel metabolic regulator. J Clin Invest. 2005;115(6):1627-35.

115. Soberg S, Sandholt CH, Jespersen NZ, Toft U, Madsen AL, von HolsteinRathlou S, Grevengoed TJ, Christensen KB, Bredie WLP, Potthoff MJ, et al. FGF21 is a sugar-induced hormone associated with sweet intake and preference in humans. Cell Metab. 2017;25(5):1045-53.e1046.

116. Chu AY, Workalemahu T, Paynter NP, Rose LM, Giulianini F, Tanaka T, Ngwa JS, Qi Q, Curhan GC, Rimm EB, et al. Novel locus including FGF21 is associated with dietary macronutrient intake. Human Molec Genet. 2013; 22(9):1895-902.

117. Tanaka T, Ngwa JS, van Rooij FJ, Zillikens MC, Wojczynski MK, Frazier-Wood AC, Houston DK, Kanoni S, Lemaitre RN, Luan J, et al. Genome-wide metaanalysis of observational studies shows common genetic variants associated with macronutrient intake. Am J Clin Nutr. 2013;97(6):1395-402.

118. Talukdar S, Owen BM, Song P, Hernandez G, Zhang Y, Zhou Y, Scott WT, Paratala $B$, Turner $T$, Smith $A$, et al. FGF21 regulates sweet and alcohol preference. Cell Metab. 2016;23(2):344-9. 
119. Wente W, Efanov AM, Brenner M, Kharitonenkov A, Koster A, Sandusky GE, Sewing S, Treinies I, Zitzer H, Gromada J. Fibroblast growth factor-21 improves pancreatic beta-cell function and survival by activation of extracellular signal-regulated kinase $1 / 2$ and Akt signaling pathways. Diabetes. 2006;55(9):2470-8.

120. Zhang X, Yeung DC, Karpisek M, Stejskal D, Zhou ZG, Liu F, Wong RL, Chow WS, Tso AW, Lam KS, et al. Serum FGF21 levels are increased in obesity and are independently associated with the metabolic syndrome in humans. Diabetes. 2008;57(5):1246-53.

121. Maack T, Johnson V, Kau ST, Figueiredo J, Sigulem D. Renal filtration, transport, and metabolism of low-molecular-weight proteins: a review. Kidney Int. 1979;16(3):251-70.

122. Wu AL, Kolumam G, Stawicki S, Chen Y, Li J, Zavala-Solorio J, Phamluong K, Feng B, Li L, Marsters S, et al. Amelioration of type 2 diabetes by antibodymediated activation of fibroblast growth factor receptor 1. Sci Transl Med. 2011;3(113):113ra126.

123. Gaich G, Chien JY, Fu H, Glass LC, Deeg MA, Holland WL, Kharitonenkov A, Bumol T, Schilske HK, Moller DE. The effects of LY2405319, an FGF21 analog, in obese human subjects with type 2 diabetes. Cell Metab. 2013;18(3):333-40.

124. Franks PW, Pearson E, Florez JC. Gene-environment and gene-treatment interactions in type 2 diabetes: progress, pitfalls, and prospects. Diabetes Care. 2013;36(5):1413-21.

125. Hivert MF, Christophi CA, Franks PW, Jablonski KA, Ehrmann DA, Kahn SE, Horton ES, Pollin TI, Mather KJ, Perreault L, et al. Lifestyle and metformin ameliorate insulin sensitivity independently of the genetic burden of established insulin resistance variants in diabetes prevention program participants. Diabetes. 2016;65(2):520-6.

126. Cartee GD. Roles of TBC1D1 and TBC1D4 in insulin- and exercise-stimulated glucose transport of skeletal muscle. Diabetologia. 2015;58(1):19-30.

127. Maher AC, McFarlan J, Lally J, Snook LA, Bonen A. TBC1D1 reduces palmitate oxidation by inhibiting beta-HAD activity in skeletal muscle. Am J Physiol Regul Integr Comp Physiol. 2014;307(9):R1115-23.

128. Moltke I, Grarup N, Jorgensen ME, Bjerregaard P, Treebak JT, Fumagalli M, Korneliussen TS, Andersen MA, Nielsen TS, Krarup NT, et al. A common Greenlandic TBC1D4 variant confers muscle insulin resistance and type 2 diabetes. Nature. 2014;512(7513):190-3.

129. Dash S, Sano H, Rochford JJ, Semple RK, Yeo G, Hyden CS, Soos MA, Clark J, Rodin A, Langenberg C, et al. A truncation mutation in TBC1D4 in a family with acanthosis nigricans and postprandial hyperinsulinemia. Proc Natl Acad Sci U S A. 2009;106(23):9350-5.

130. Schrauwen $P$, van Marken Lichtenbelt WD. Combatting type 2 diabetes by turning up the heat. Diabetologia. 2016;59(11):2269-79.

131. Vissing K, Andersen JL, Schjerling P. Are exercise-induced genes induced by exercise? FASEB J. 2005;19(1):94-6.

132. Rosqvist F, Iggman D, Kullberg J, Cedernaes J, Johansson HE, Larsson A, Johansson L, Ahlstrom H, Arner P, Dahlman I, et al. Overfeeding polyunsaturated and saturated fat causes distinct effects on liver and visceral fat accumulation in humans. Diabetes. 2014;63(7):2356-68.

133. Perfilyev A, Dahlman I, Gillberg L, Rosqvist F, Iggman D, Volkov $P$, Nilsson E, Riserus $U$, Ling C. Impact of polyunsaturated and saturated fat overfeeding on the DNA-methylation pattern in human adipose tissue: a randomized controlled trial. Am J Clin Nutr. 2017;105(4):991-1000.

134. Harris ED. Biochemical Facts behind the Definition and Properties of Metabolites. FDA. https://www.fda.gov/ohrms/dockets/ac/03/briefing/ 3942b1_08_Harris\%20Paper.pdf. Accessed 18 July 2017.

135. Kujala UM, Makinen VP, Heinonen I, Soininen P, Kangas AJ, Leskinen TH, Rahkila P, Wurtz P, Kovanen V, Cheng S, et al. Long-term leisure-time physical activity and serum metabolome. Circulation. 2013;127(3):340-8.

136. Garcia-Perez I, Posma JM, Gibson R, Chambers ES, Hansen TH, Vestergaard $H$, Hansen T, Beckmann M, Pedersen O, Elliott P, et al. Objective assessment of dietary patterns by use of metabolic phenotyping: a randomised, controlled, crossover trial. Lancet Diabet Endocrinol. 2017;5(3):184-95.

137. Relman DA. The human microbiome: ecosystem resilience and health. Nutr Rev. 2012;70 Suppl 1:S2-9.

138. Zeevi D, Korem T, Zmora N, Israeli D, Rothschild D, Weinberger A, Ben-Yacov O, Lador D, Avnit-Sagi T, Lotan-Pompan M, et al. Personalized nutrition by prediction of glycemic responses. Cell. 2015;163(5):1079-94.

139. Nelson MR, Tipney H, Painter JL, Shen J, Nicoletti P, Shen Y, Floratos A, Sham PC, Li MJ, Wang J, et al. The support of human genetic evidence for approved drug indications. Nat Genet. 2015;47(8):856-60.
140. Fan S, Hansen ME, Lo Y, Tishkoff SA. Going global by adapting local: A review of recent human adaptation. Science. 2016;354(6308):54-9.

141. Price ND, Magis AT, Earls JC, Glusman G, Levy R, Lausted C, McDonald DT, Kusebauch U, Moss CL, Zhou Y, et al. A wellness study of 108 individuals using personal, dense, dynamic data clouds. Nat Biotechnol. 2017;35(8):747-56.

142. Ritchie MD, Holzinger ER, Li R, Pendergrass SA, Kim D. Methods of integrating data to uncover genotype-phenotype interactions. Nat Rev Genet. 2015;16(2):85-97.

\section{Submit your next manuscript to BioMed Central and we will help you at every step:}

- We accept pre-submission inquiries

- Our selector tool helps you to find the most relevant journal

- We provide round the clock customer support

- Convenient online submission

- Thorough peer review

- Inclusion in PubMed and all major indexing services

- Maximum visibility for your research

Submit your manuscript at www.biomedcentral.com/submit

) Biomed Central 